\title{
Synthesis and application of solar cells of poly (3-decylthiophene)/N/titanium dioxide hybrid
}

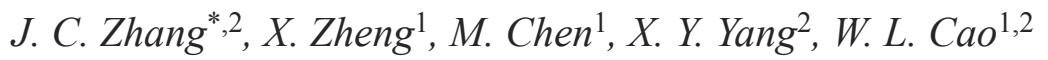 \\ ${ }^{1}$ Institute of Modern Catalysis, Beijing University of Chemical Technology, State Key Laboratory of Chemical Resource \\ Engineering, Beijing 100029, China \\ ${ }^{2}$ Institute of Science and Technology, Haikou 571126, China
}

Received 6 September 2010; accepted in revised form 23 November 2010

\begin{abstract}
An organic-inorganic nanocomposite material of poly (3-decylthiophene) and titanium dioxide doped with $\mathrm{N}$ $\left(\mathrm{P} 3 \mathrm{DT} / \mathrm{N} / \mathrm{TiO}_{2}\right)$ were synthesized. Structures were characterized using X-ray diffraction (XRD), infrared spectroscopy (IR), transmission electron microscopy (TEM), and X-ray photoelectron spectroscopy (XPS). Optical and electrochemical properties were determined using UV-visible spectroscopy, fluorescence spectroscopy, and cyclic voltammetry. These tests indicated that $\mathrm{P} 3 \mathrm{DT} / \mathrm{N} / \mathrm{TiO}_{2}$ was a new p-n semiconductor photoelectric material, and the solar cell prepared with $\mathrm{P} 3 \mathrm{DT} / \mathrm{N} / \mathrm{TiO}_{2}$ performed well.
\end{abstract}

Keywords: polymer composites, $\mathrm{P} 3 \mathrm{DT} / \mathrm{N} / \mathrm{TiO} \mathrm{O}_{2}$ nanocomposite material, - $n$ semiconductor, photoelectric properties, solar cells

\section{Introduction}

Conducting polymers with highly-extended $\pi$-electron systems in their main chains have attracted much interest [1-4]. Polymers and metal oxides have been studied for many years for their independent electrical, optical, and mechanical properties [5]. Composites of these polymers with inorganic matter, combining the different properties of components, are considered remarkable advanced materials [6].

Polythiophene (PT) was widely studied as donor material in organic solar cells $[7,8]$. Sharma et al. [9] studied the optical and photoelectrical properties of liquid state photoelectrochemical cells (PECs) based on photoactive electrodes made of poly (phenyl azo methane thiophene) (PPAT) and a composite film of nano-crystalline titanium dioxide (nc$\mathrm{TiO}_{2}$ ) and PPAT, and found that the composite film was better than PPAT by itself. Visy et al. [10] pre- pared Poly (3-octyl-thiophene) (POT) and ferrous oxalate composite in order to get a better material. Suresh et al. [11] applied poly (3-phenyl hydrazone thiophene) (PPHT) and titanium dioxide composite in solar cells and obtained some improved results. Huisman et al. [12] replaced the titanium dioxide layer of solar cells with a PT/titanium dioxide composite layer and obtained solar cells that clearly show that area enlargement is beneficial to the conversion efficiency. However, there is no paper on poly (3-alkylthiophene) (P3AT) and doping inorganic nanocomposites. P3AT has good solubility, processability, stability, and electrical activity, and is convenient for mass production. The regular structure of P3AT can be obtained easily, and therefore P3AT was considered as one of the best donor materials. In this paper, the synthesis of $\mathrm{P} 3 \mathrm{DT} / \mathrm{N} / \mathrm{TiO}_{2}$ nanocomposite materials was introduced in detail. Chemical interactions in the material were found by

\footnotetext{
${ }^{*}$ Corresponding author, e-mail: zhangjc1@mail.buct.edu.cn
} (c) BME-PT 
X-ray diffraction, IR spectroscopy, and X-ray photoelectron spectroscopy. Ultraviolet-visible and luminescence measurements indicated that these $\mathrm{P} 3 \mathrm{DT} / \mathrm{N} / \mathrm{TiO}_{2}$ nanocomposites have excellent photoelectric properties. Electrochemical results indicated that the band gap of the nanocomposite hybrid was lower than that of the components.

\section{Experimental section}

\subsection{Materials}

3-Decylthiophene (Aldrich), $\mathrm{FeCl}_{3}$ (Aldrich) and $\mathrm{TiCl}_{4}$ (Aldrich) was used without further purification. FTO (Fluorine Tin Oxides) was commercially available. $\mathrm{LiClO}_{4}$ was obtained from $\mathrm{LiClO}_{4} \cdot 3 \mathrm{H}_{2} \mathrm{O}$ (Aldrich).

\subsection{Synthesis of $\mathrm{PBDT} / \mathrm{N} / \mathrm{TiO}_{2}$ nanocomposites}

The conducting poly (3-decylthiophene) was synthesized with $\mathrm{Fe}$ (III) as catalyst and 3-decylthiophene monomer as material according to Ref. [13]. 3-decylthiophene monomer and chloroform were added to a $100 \mathrm{ml}$ flask and ultrasonically dispersed for $15 \mathrm{~min}$. The temperature of system was controlled at $0^{\circ} \mathrm{C} . \mathrm{FeCl}_{3}$ was dissolved in chloroform, and added dropwise to the flask. The reaction mixture was stirred under high-purity nitrogen for $8 \mathrm{~h}$. The product was slowly added to methanol, precipitated, filtered and subjected to Soxhlet extraction with methanol for $20 \mathrm{~h}$. The P3DT was then dried under vacuum at room temperature. P3DT $(0.01 \mathrm{~g})$ was dissolved in chloroform $(2 \mathrm{ml})$ and dropped evenly on a clean quartz glass and ITO (Indium Tin Oxides) conductive glass. Red-brown P3DT films were obtained on vacuum drying the glasses.

Nano-N/TiO 2 was prepared with $\mathrm{TiCl}_{4}$ as material according to Ref. [14]. Surfactant polyethylene glycol (PEG 800) was added to $0.3 \mathrm{~mol} / 1$ of $\mathrm{TiCl}_{4}$, followed by stirring vigorously at ambient temperature. The $\mathrm{pH}$ of the solution was adjusted to $5-6$ by dripping ammonia. The sol was filtered and washed with ammonia until no presence of $\mathrm{Cl}^{-}$, and then transferred into a PTFE autoclave $(100 \mathrm{ml})$ and maintained at $240^{\circ} \mathrm{C}$ for $12 \mathrm{~h}$. Then the sol was washed by ethanol until no water existed. The obtained alcogel was dried at room temperature, and calcined at $500^{\circ} \mathrm{C}$ for $1 \mathrm{~h}$ to give the nano$\mathrm{N} / \mathrm{TiO}_{2} \cdot \mathrm{N} / \mathrm{TiO}_{2}(0.01 \mathrm{~g})$ was suspensed in isopropyl alcohol $(2 \mathrm{ml})$ and dropped evenly on clean quartz glasses and ITO. White $\mathrm{N} / \mathrm{TiO}_{2}$ films were obtained after drying in vacuum.

About $0.01 \mathrm{~g}$ of P3DT was dissolved in $2 \mathrm{ml}$ of chloroform, and $0.05 \mathrm{~g}$ of $\mathrm{N} / \mathrm{TiO}_{2}$ was added. The mixture was ultrasonic shocked for $3 \mathrm{~h}$ at $40^{\circ} \mathrm{C}$ to get a uniform liquid. $\mathrm{P} 3 \mathrm{DT} / \mathrm{N} / \mathrm{TiO}_{2}$ nanocomposite powder was obtained by vacuum drying at room temperature. The uniform mixture liquid obtained above was dropped evenly on a clean quartz glass and ITO conductive glass. The red-brown P3DT/N/ $\mathrm{TiO}_{2}$ nanocomposite films were prepared by the vacuum drying method.

\subsection{Preparation of dye-sensitized solar cell}

The prepared $\mathrm{TiCl}_{4}$ sol-gel was dropped on the FTO substrate and spun on a uniform plastic machine at a rate of $3000 \mathrm{r} / \mathrm{min}$ for 20 seconds. The prepared anatase $\mathrm{TiO}_{2}$ powder of particle size about $14 \mathrm{~nm}$ was dropped on the sol-gel coated FTO substrate, and suffered spinning by the machine at a rate of $3000 \mathrm{r} / \mathrm{min}$ for 20 seconds. After being sintered at $450^{\circ} \mathrm{C}$ for $30 \mathrm{~min}$, a good film was produced. $\mathrm{H}_{2} \mathrm{PtCl}_{6}$ was evenly dropped on another FTO substrate and burnt at $380^{\circ} \mathrm{C}$ for $30 \mathrm{~min}$ before the Pt electrode was obtained. The anode was sensitized by P3DT and $\mathrm{P} 3 \mathrm{DT} / \mathrm{N} / \mathrm{TiO}_{2}$ chloroform solution, and then packaged by the prepared Pt electrode, followed by the addition of electrolyte.

\subsection{Structural characterization}

$\mathrm{X}$-ray diffraction (XRD) measurements were performed using a Shimadzu HR6000X $(\mathrm{Cu}$ target $\mathrm{X}$ tube, voltage $40.0 \mathrm{kV}$, current $30.0 \mathrm{~mA}$, scan angle $3-80^{\circ}$ ). Infrared spectroscopy (IR) spectra were recorded in the range of $400-4000 \mathrm{~cm}^{-1}$ by a prestige-21IR spectrophotometer with $\mathrm{KBr}$ pellet. Transmission electron microscope (TEM) measurements were performed using a HITACHI-800 transmission electron microscope. X-ray photoelectron spectroscopy (XPS) analyses were conducted by an ESCALAB 250 in which the electronic binding energy of the samples were measured.

\subsection{Performance characterization}

UV-visible spectra were measured using a Hitachi U-3010 spectrophotometer (Scan range: 200$800 \mathrm{~nm}$ ). The excitation and emission spectra measurements were performed on a Hitachi F-7000 spectrofluorophotometer equipped with a $150 \mathrm{~W}$ xenon 
lamp as the excitation source. The spectra were recorded with monochromator slit width of $1.5 \mathrm{~nm}$ on both the excitation and emission sides. Cyclic voltammetry $(\mathrm{CV})$ measurements were carried out with a Potentiostiostat/Galvanostat (EG\&G PAR Model 283). The counterelectrode was platinum and the reference electrode was non-aqueous $\mathrm{Ag} / \mathrm{Ag}^{+}$. The $\mathrm{CV}$ curves were record in acetonitrile with $0.01 \mathrm{~mol} / 1 \mathrm{LiClO}_{4}$ as electrolyte at a scan rate of $50 \mathrm{mV} / \mathrm{S}$. Before using, the solution was insufflated with $\mathrm{N}_{2}$ for $30 \mathrm{~min}$.

Current-voltage (I-V) measurements were taken in air at room temperature $(298 \mathrm{~K})$ using a Keithley 236 high current source power meter under whitelight illumination from a $1000 \mathrm{~W}$ Xenon lamp. The light intensity was about $100 \mathrm{~mW} / \mathrm{cm}^{2}$ on the sample surfaces as measured by a photodetector. To measure the decay, we recorded the short circuit current and open circuit voltage as a function of the illumination time.

\section{Results and discussion}

\subsection{XRD characterization of $\mathrm{TiO}_{2}, \mathrm{~N} / \mathrm{TiO}_{2}$, P3DT and P3DT/N/TiO 2}

The XRD patterns of $\mathrm{TiO}_{2}, \mathrm{~N} / \mathrm{TiO}_{2}, \mathrm{P} 3 \mathrm{DT}$ and $\mathrm{P} 3 \mathrm{DT} / \mathrm{N} / \mathrm{TiO}_{2}$ are presented in Figure 1. In XRD patterns of $\mathrm{TiO}_{2}$ and $\mathrm{N} / \mathrm{TiO}_{2}$, the peaks at 25.32, 37.88, $48.08,53.80,55.04$ and $62.80^{\circ}$ are assigned to the (101), (004), (200), (105), (211) and (215) lattice planes, which are attributed to the signals of the anatase phase. There is little difference in two curves, so doping elements are highly monodispersed in the $\mathrm{TiO}_{2}$. By using the Scherrer formula, it is found that the average $\mathrm{TiO}_{2}$ particle size is $22.22 \mathrm{~nm}$ while $\mathrm{N} / \mathrm{TiO}_{2}$ is $13.69 \mathrm{~nm}$. In the XRD pattern of P3DT, the 'hill' at $15-28^{\circ}$ is associated with the amorphous phase, while the reflections at around $5,10,15.07^{\circ}$ and $21.72^{\circ}$ can reflect crystalline structure. The reflection at $21.72^{\circ}$ is attributed to the interchain distance between $\pi$-stacking oxidized chains. The Bragg equation gives $0.35 \mathrm{~nm}$ for this distance. The reflections at 5, 10, and $15.07^{\circ}$ Bragg angles confirm the layered structure of P3DT as having a dominant first-order reflection at $2 \theta=5^{\circ}$ and a lamellar interlayer spacing of $1.81 \mathrm{~nm}$ [10]. The diffraction peak of P3DT is quite narrow, which shows the high degree of crystallization, plane structure, and the high regularity of P3DT segments. For the $\mathrm{P} 3 \mathrm{DT} / \mathrm{N} / \mathrm{TiO}_{2}$ nanocomposite, the XRD pattern

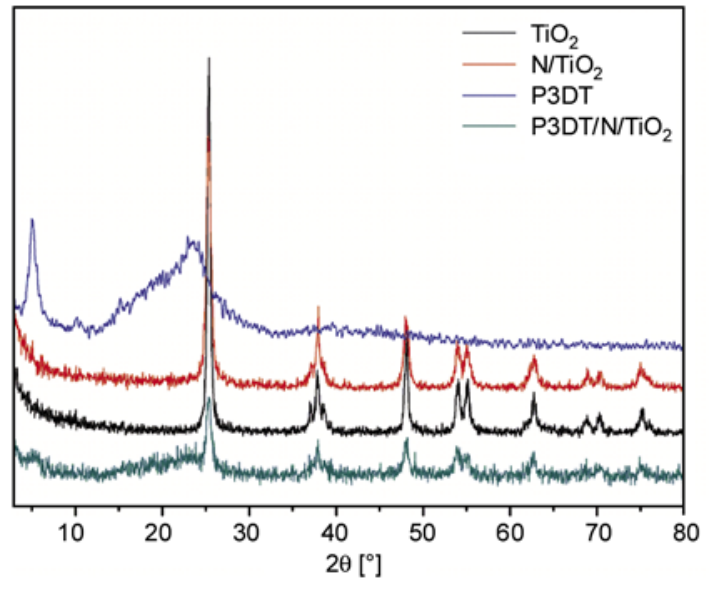

Figure 1. XRD patterns of $\mathrm{TiO}_{2}, \mathrm{~N} / \mathrm{TiO}_{2}, \mathrm{P} 3 \mathrm{DT}$ and $\mathrm{P} 3 \mathrm{DT} / \mathrm{N} / \mathrm{TiO}_{2}$

mainly shows the strong $\mathrm{N} / \mathrm{TiO}_{2}$ peaks. The characteristic P3DT broad peak can not be seen on the XRD pattern of P3DT/N/TiO 2 nanocomposite. The XRD pattern of the nanocomposite has higher background intensity, lower diffraction peak intensity, decreased interplanar spacing, and reduced sharpness of the peak profiles than $\mathrm{N} / \mathrm{TiO}_{2}$, confirming the chemical interaction between P3DT and nano$\mathrm{N} / \mathrm{TiO}_{2}$.

\subsection{IR results of $\mathrm{N} / \mathrm{TiO}_{2}, \mathrm{P} 3 \mathrm{DT}$ and $\mathrm{P3DT} / \mathrm{N} / \mathrm{TiO}_{2}$}

The FT-IR spectra are shown in Figure 2. In the spectrum of $\mathrm{N} / \mathrm{TiO}_{2}$, the Ti-O-Ti bond absorption is at about $497 \mathrm{~cm}^{-1}$ [15]. In the spectrum of P3DT, there is a low-intensity peak at $3056 \mathrm{~cm}^{-1}$ that can be attributed to the thiophene ring $\mathrm{C}-\mathrm{H}$ stretching vibration, which is corresponding to the out-ofplane bending of the thiophene ring $\mathrm{C}-\mathrm{H}$ at 830 and $720 \mathrm{~cm}^{-1}$. The bands at 2921 and $2853 \mathrm{~cm}^{-1}$ belong

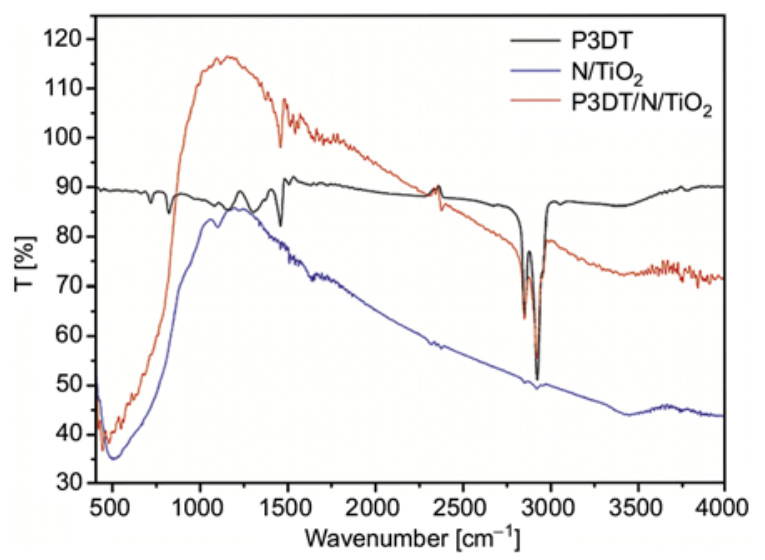

Figure 2. FT-IR spectras of $\mathrm{N} / \mathrm{TiO}_{2}, \mathrm{P} 3 \mathrm{DT}$ and $\mathrm{P} 3 \mathrm{DT} / \mathrm{N} /$ $\mathrm{TiO}_{2}$ 
to the $\mathrm{C}-\mathrm{H}$ of $\mathrm{CH}_{2}$ or $\mathrm{CH}_{3}$ symmetric and asymmetric stretching, which are corresponding to the asymmetric and symmetric deformations at 1305 and $1459 \mathrm{~cm}^{-1}$. The bands at 1499 and $665 \mathrm{~cm}^{-1}$ correspond to the symmetric vibration of the $\mathrm{C}=\mathrm{C}$ and the asymmetric vibration of the $\mathrm{C}-\mathrm{S}$, respectively. Bands coming from both $\mathrm{N} / \mathrm{TiO}_{2}$ and P3DT are observed in the spectrum of $\mathrm{P} 3 \mathrm{DT} / \mathrm{N} / \mathrm{TiO}_{2}$ nanocomposite, whereas the bands originating from $\mathrm{N} / \mathrm{TiO}_{2}$ and P3DT are located at low wavenumbers. In addition, several new peaks appear at 3840 , $3745,580,476$, and $418 \mathrm{~cm}^{-1}$.

\subsection{TEM measurements of nano- $\mathrm{N} / \mathrm{TiO}_{2}$}

Figure 3 demonstrates the TEM results of nano$\mathrm{N} / \mathrm{TiO}_{2}$. It can be seen that the particle size is between $13-15 \mathrm{~nm}$, the result is basically the same with the Scherrer formula. The particles have good dispersibility and clear mesh structure. This is attributed to the use of alcohol exchange in the preparation of powder to eliminate the liquid surface tension and reduce the agglomeration of particles during the burning process; thereby high
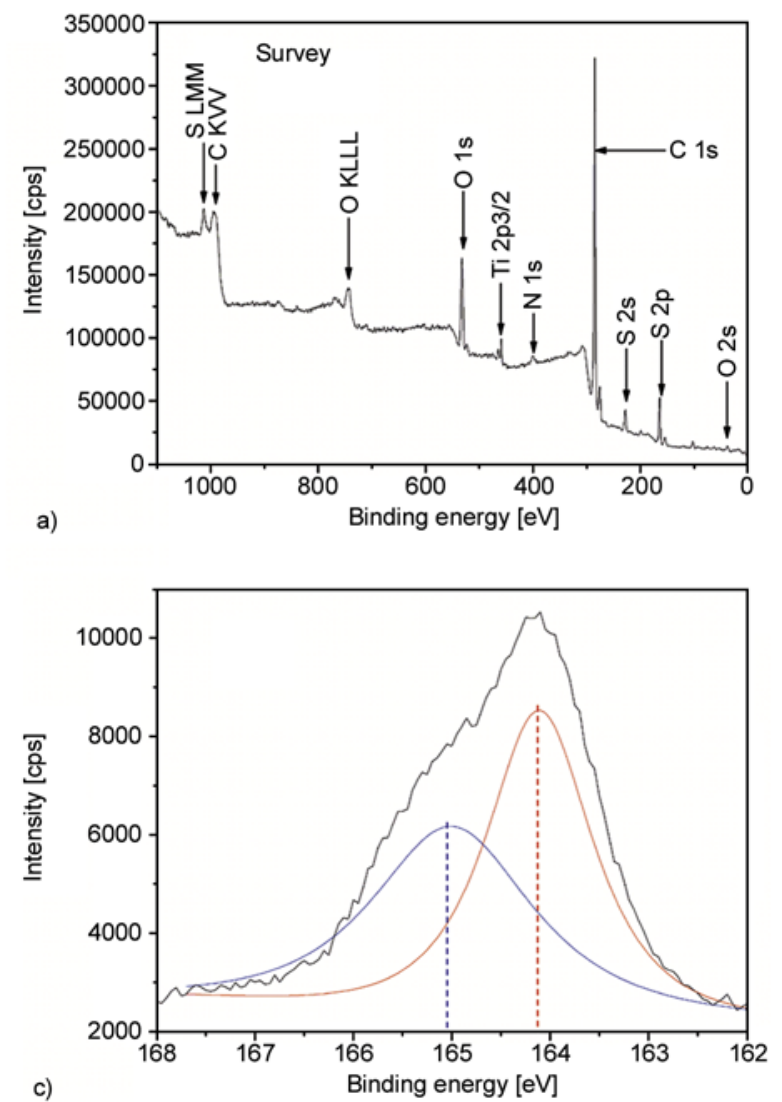

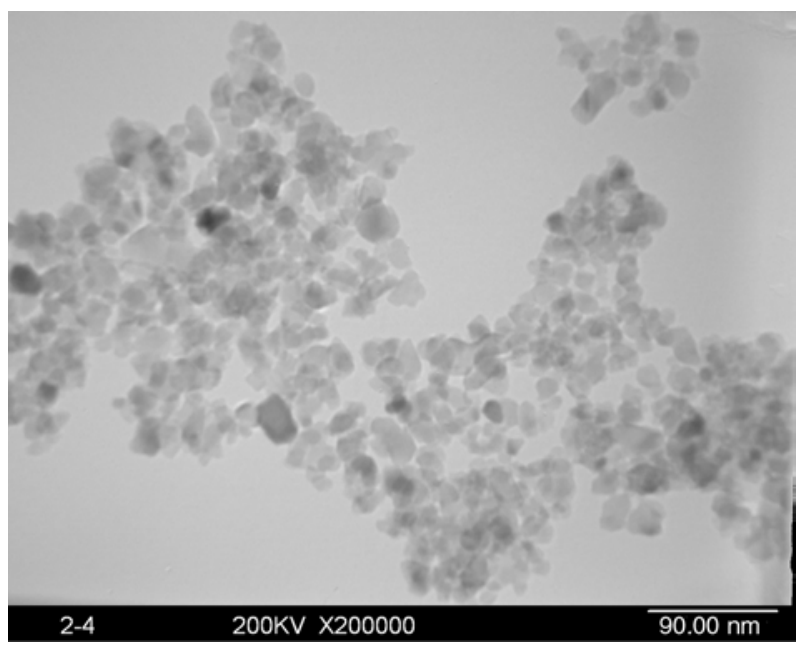

Figure 3. TEM pattern of nano- $\mathrm{N} / \mathrm{TiO}_{2}$

surface area, small particle size, and good dispersion of nano-particles can be obtained.

\subsection{XPS characterization of $\mathrm{N} / \mathrm{TiO}_{2}$, P3DT and $\mathrm{P3DT} / \mathrm{N} / \mathrm{TiO}_{2}$}

The high-resolution XPS spectra are shown in Figure $4 \mathrm{a}-4 \mathrm{~d}$. In the $\mathrm{P} 3 \mathrm{DT} / \mathrm{N} / \mathrm{TiO}_{2}$ sample (Figure $4 \mathrm{a}$ ), the XPS spectrum shows $\mathrm{C}, \mathrm{O}, \mathrm{S}, \mathrm{Ti}$ and $\mathrm{N}$ peaks.
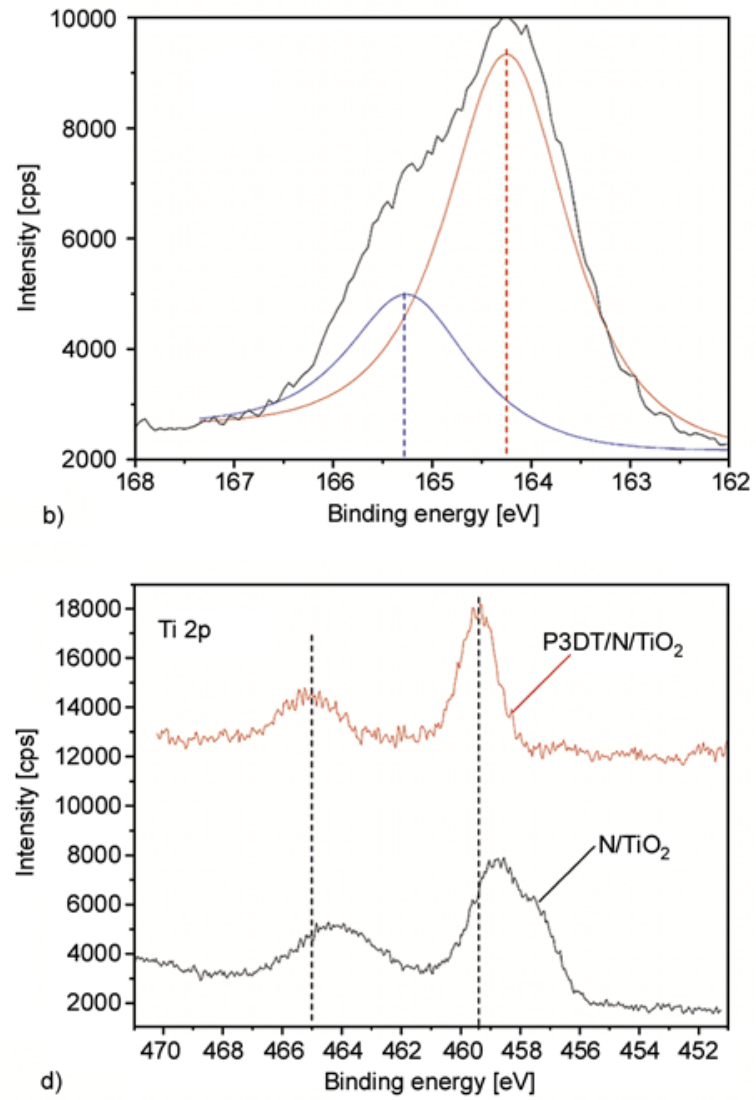

Figure 4. XPS spectras of $\mathrm{P} 3 \mathrm{DT} / \mathrm{N} / \mathrm{TiO}_{2}$ (a), the sulfur peaks in $\mathrm{P} 3 \mathrm{DT}(\mathrm{b})$, the sulfur peaks in $\mathrm{P} 3 \mathrm{DT} / \mathrm{N} / \mathrm{TiO}{ }_{2}(\mathrm{c})$ and $\mathrm{Ti} 2 \mathrm{p}$ peaks $(d)$ 
Figure $4 \mathrm{~b}$ shows the sulfur peaks in P3DT. Two sulfur peaks (S 2p3/2) are found, one with a binding energy of $164.3 \mathrm{eV}$ for neutral thiophene units in the polymer chain and the other with a binding energy of $165.3 \mathrm{eV}$ for oxidized thiophene units [16]. Figure $4 \mathrm{c}$ shows the sulfur peaks in P3DT/N/ $\mathrm{TiO}_{2}$. There are also two sulfur peaks ( $\mathrm{S} 2 \mathrm{p} 3 / 2$ ), one with a binding energy of $164.1 \mathrm{eV}$ for neutral thiophene units in the polymer chain and the other with a binding energy of $165.1 \mathrm{eV}$ for oxidized thiophene units, indicating that the $\mathrm{S}$ atom of P3DT will interact with some other atom except the $\mathrm{C}$ atom of P3DT after composite reaction. Figure $4 d$ shows the displacement of Ti $2 p$ peaks after composite reaction. The binding energy became larger, indicating that there were electrons gained and lost during the complex process and $\mathrm{N} / \mathrm{TiO}_{2}$ combined with P3DT at the Ti position. Comparing Figure $4 \mathrm{~b}$ with Figure $4 \mathrm{c}$, we find the sulfur peaks are displaced after composite formation, and P3DT combined with $\mathrm{N} / \mathrm{TiO}_{2}$ at the sulfur position.

\subsection{UV-Vis spectra of $\mathrm{N} / \mathrm{TiO}_{2}, \mathrm{P} 3 \mathrm{DT}$ and P3DT/N/TiO}

The UV-Vis spectra of the $\mathrm{N} / \mathrm{TiO}_{2}$ film, P3DT film and $\mathrm{P} 3 \mathrm{DT} / \mathrm{N} / \mathrm{TiO}_{2}$ nanocomposite film are presented in Figure 5. The spectrum of $\mathrm{N} / \mathrm{TiO}_{2}$ shows the fundamental absorption of UV light ranging from 250 to $420 \mathrm{~nm}$ by the Ti-O bond. The UV-Vis spectrum of P3DT with maximum adsorption at a wavelength of about $457 \mathrm{~nm}$ for the $\pi \rightarrow \pi^{*}$ transition indicates the formation of the big $\pi$ conjugate structure along the main chain $[17,18]$. From the spectrum of $\mathrm{P} 3 \mathrm{DT} / \mathrm{N} / \mathrm{TiO}_{2}$ nanocomposite film, it

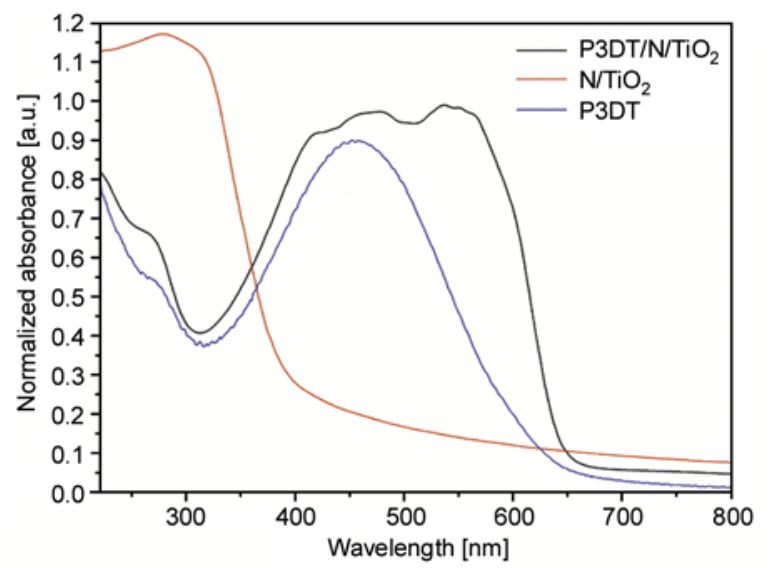

Figure 5. $\mathrm{UV}-\mathrm{Vis}$ spectras of $\mathrm{N} / \mathrm{TiO}_{2}, \mathrm{P} 3 \mathrm{DT}$ and $\mathrm{P} 3 \mathrm{DT} / \mathrm{N} /$ $\mathrm{TiO}_{2}$ can be seen that there are two absorption bands with maximum wavelengths of 270 and $500 \mathrm{~nm}$ in the ultraviolet region and visible light region, respectively. Comparing with the spectra of $\mathrm{N} / \mathrm{TiO}_{2}$ and $\mathrm{P} 3 \mathrm{DT}$, we find the $\mathrm{P} 3 \mathrm{DT} / \mathrm{N} / \mathrm{TiO}_{2}$ nanocomposite film absorbs much more UV-Vis light. It is reasonable to believe that the $\mathrm{P} 3 \mathrm{DT} / \mathrm{N} / \mathrm{TiO}_{2}$ nanocomposite will perform better in semiconductors than $\mathrm{P} 3 \mathrm{DT}$ and $\mathrm{N} / \mathrm{TiO}_{2}$.

\subsection{Fluorescence spectra of $\mathrm{N} / \mathrm{TiO}_{2}, \mathrm{P3DT}$, and $\mathrm{P3DT} / \mathrm{N} / \mathrm{TiO}_{2}$}

The fluorescence spectra of the $\mathrm{N} / \mathrm{TiO}_{2}$ film, P3DT film and $\mathrm{P} 3 \mathrm{DT} / \mathrm{N} / \mathrm{TiO}_{2}$ nanocomposite film are shown in Figure 6. Two emission peaks can be seen with the maximum emission at 386 and $454 \mathrm{~nm}$ in the fluorescence spectrum of $\mathrm{N} / \mathrm{TiO}_{2}$. There is an emission peak with the maximum emission at $630 \mathrm{~nm}$ in the spectrum of P3DT. The fluorescence spectrum of the $\mathrm{P} 3 \mathrm{DT} / \mathrm{N} / \mathrm{TiO}_{2}$ nanocomposite film is totally different from that of either P3DT or $\mathrm{N} / \mathrm{TiO}_{2}$. It exhibits new optical property for the new chemical interaction between $\mathrm{P} 3 \mathrm{DT}$ and $\mathrm{N} / \mathrm{TiO}_{2}$ with three emission peaks at 350,483, and $726 \mathrm{~nm}$. It proves that $\mathrm{P} 3 \mathrm{DT} / \mathrm{N} / \mathrm{TiO}_{2}$ is a new compound.

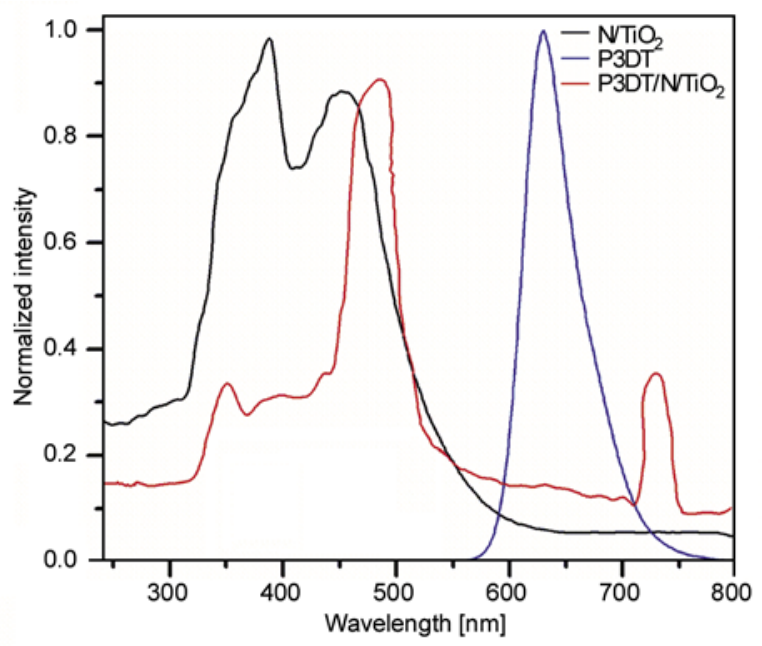

Figure 6. Fluorescence spectras of $\mathrm{N} / \mathrm{TiO}_{2}, \mathrm{P} 3 \mathrm{DT}$ and $\mathrm{P} 3 \mathrm{DT} / \mathrm{N} / \mathrm{TiO}_{2}$

\subsection{Cyclic voltammetry}

Figure $7 \mathrm{a}-7 \mathrm{~d}$. show the cyclic voltammetry results of the $\mathrm{TiO}_{2}$ film, N/TiO 2 film, P3DT solid film and $\mathrm{P} 3 \mathrm{DT} / \mathrm{N} / \mathrm{TiO}_{2}$ nanocomposite film. The oxidation potentials and redox of electrode and the bandgap $E_{\mathrm{g}}$ are listed in Table 1. 
Table 1. The frontline molecular orbital and energy gap of $\mathrm{TiO}_{2}, \mathrm{~N} / \mathrm{TiO}_{2}, \mathrm{P} 3 \mathrm{DT}$ and $\mathrm{P} 3 \mathrm{DT} / \mathrm{N} / \mathrm{TiO}_{2}$ nanocomposite

\begin{tabular}{|l|c|c|c|c|c|}
\hline \multicolumn{1}{|c|}{ Sample } & $\begin{array}{c}\boldsymbol{\Phi}_{\mathbf{o x}} \\
{[\mathbf{e V}]}\end{array}$ & $\begin{array}{c}\boldsymbol{\Phi}_{\text {red }} \\
{[\mathbf{e V}]}\end{array}$ & $\begin{array}{c}\mathbf{E}_{\mathbf{H O M O}} \\
{[\mathbf{e V}]}\end{array}$ & $\begin{array}{c}\mathbf{E}_{\mathbf{L U M O}} \\
{[\mathbf{e V}]}\end{array}$ & $\begin{array}{c}\mathbf{E}_{\mathbf{g}} \\
{[\mathbf{e V}]}\end{array}$ \\
\hline $\mathrm{TiO}_{2}$ & 2.14 & -1.01 & -6.58 & -3.43 & 3.15 \\
\hline $\mathrm{N} / \mathrm{TiO}_{2}$ & 2.14 & -0.75 & -6.58 & -3.69 & 2.89 \\
\hline $\mathrm{P} 3 \mathrm{DT}$ & 0.51 & -0.62 & -4.95 & -3.82 & 1.13 \\
\hline $\mathrm{P} 3 \mathrm{DT} / \mathrm{N} / \mathrm{TiO}_{2}$ & 0.30 & -0.67 & -4.74 & -3.77 & 0.97 \\
\hline
\end{tabular}

Using the Equations (1) and (2) [19, 20]:

$E_{\text {Hомо }}\left(\right.$ or $\left.E_{\mathrm{LUMO}}\right)=E_{0}+\mathrm{e} V_{\text {ox }}\left(\right.$ or e $\left.V_{\text {red }}\right)$

$E_{\mathrm{g}}=E_{\mathrm{LUMO}}-E_{\mathrm{HOMO}}$

$E_{\text {Номо }}$ is the electrode potential of the highest occupied molecular orbital; $E_{0}$ is the standard electrode potential of $\mathrm{Ag} / \mathrm{Ag}^{+}$electrodes, and its value is $-4.4 \mathrm{eV}$. $\Phi_{\text {ox }}$ is the oxidation potential of electrode (as opposed to $\mathrm{Ag} / \mathrm{Ag}^{+}$electrodes). $E_{\mathrm{LUMO}}$ is the electrode potential of the lowest unoccupied molecular orbital; $\Phi_{\text {red }}$ is the redox potential of electrode (as opposed to $\mathrm{Ag} / \mathrm{Ag}^{+}$electrodes).

The initial oxidation/reduction potential can be seen in Figure 7. Table 1. shows that $\mathrm{N} / \mathrm{TiO}_{2}$ has lower
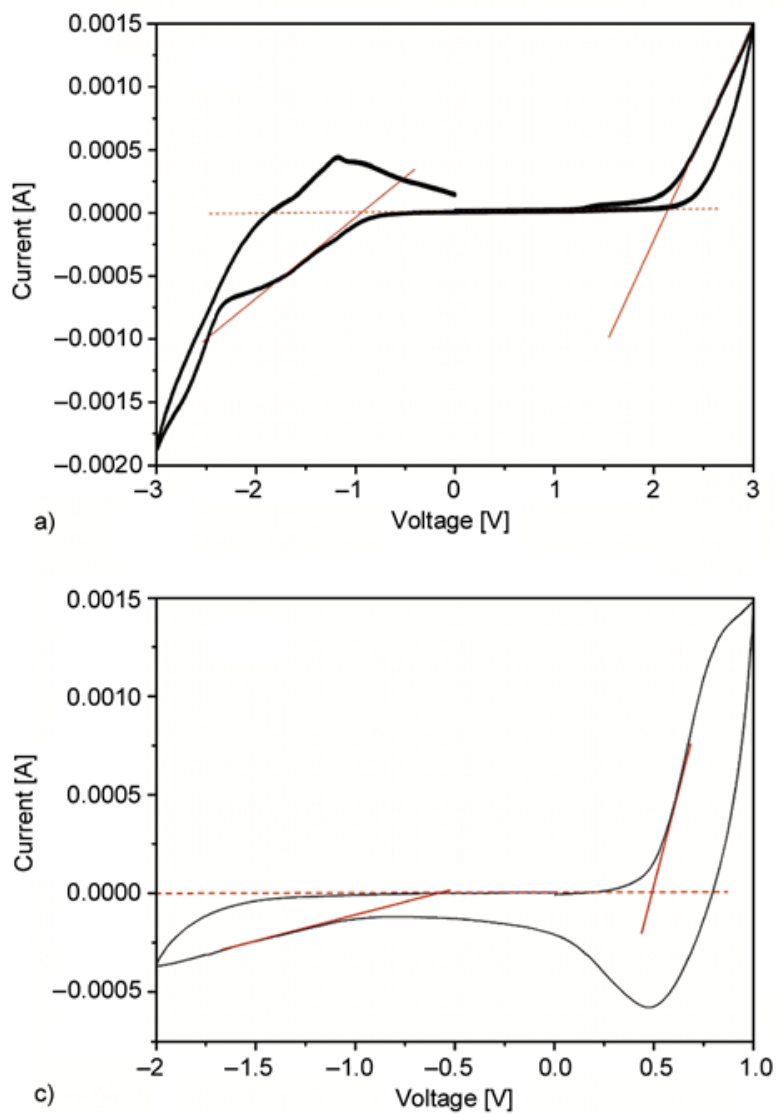

bandgap $E_{\mathrm{g}}$ than $\mathrm{TiO}_{2}$ and the bandgap $E_{\mathrm{g}}$ of P3DT/ $\mathrm{N} / \mathrm{TiO}_{2}$ is $0.97 \mathrm{eV}$ which is lower than that of $\mathrm{P} 3 \mathrm{DT}$. The results indicate that the $\mathrm{P} 3 \mathrm{DT} / \mathrm{N} / \mathrm{TiO}_{2}$ nanocomposite is a new promising $\mathrm{p}-\mathrm{n}$ type composite material.

\subsection{Results of solar cells performance test}

Figure 8. displays the photovoltaic performance of solar cells sensitized respectively by P3DT and $\mathrm{P} 3 \mathrm{DT} / \mathrm{N} / \mathrm{TiO}_{2}$ chloroform solutions, and Table 2



Figure 8. Photovoltaic performance of solar cells sensitized respectively by $\mathrm{P} 3 \mathrm{DT}$ and $\mathrm{P} 3 \mathrm{DT} / \mathrm{N} / \mathrm{TiO}_{2}$
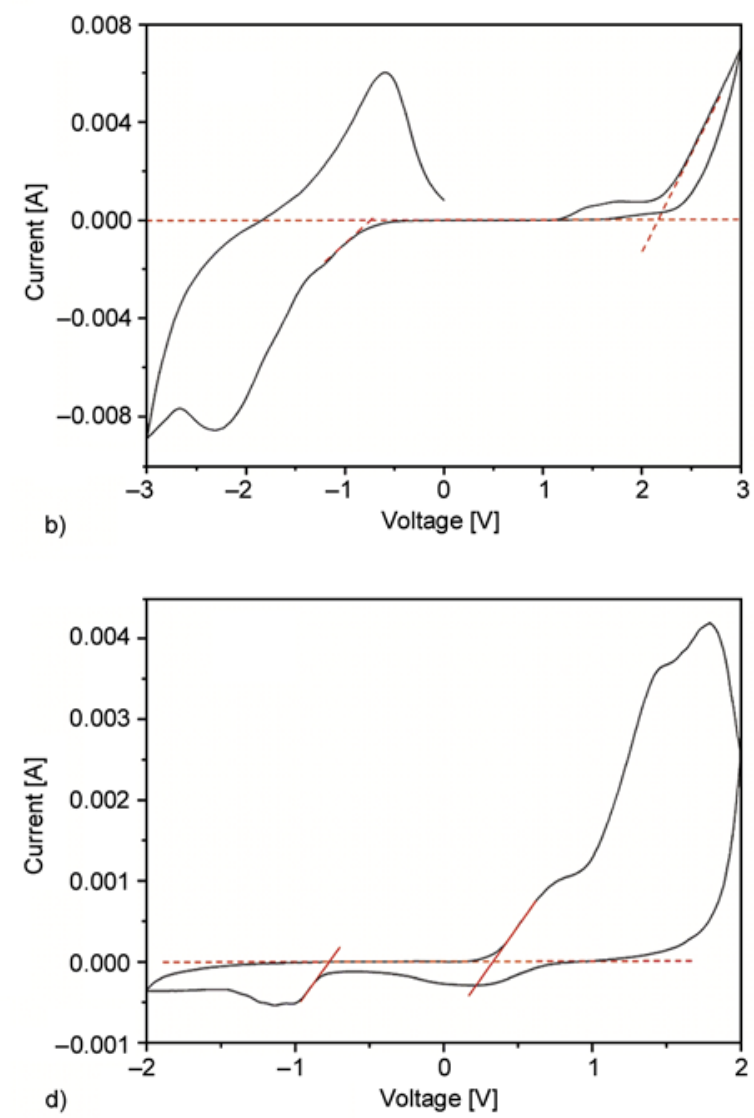

Figure 7. Cyclic voltammetry waves of $\mathrm{TiO}_{2}$ (a), N/TiO 2 (b), P3DT (c) and P3DT/N/TiO 2 (d) 
Table 2. The parameters of dye-sensitized solar cells

\begin{tabular}{|l|c|c|c|c|c|}
\hline \multicolumn{1}{|c|}{ Cells } & $\begin{array}{c}\mathbf{V}_{\text {oc }} \\
{[\mathbf{V}]}\end{array}$ & $\begin{array}{c}\mathbf{J}_{\text {sc }} \\
{\left[\mathbf{m A} \cdot \mathbf{c m}^{-2}\right]}\end{array}$ & $\begin{array}{c}\mathbf{P}_{\max } \\
{[\mathbf{m W}]}\end{array}$ & $\begin{array}{c}\mathbf{\eta} \\
{[\mathbf{\%}]}\end{array}$ & $\mathbf{F F}$ \\
\hline $\mathrm{P} 3 \mathrm{DT}$ & 0.401 & 0.733 & 0.0172 & 0.115 & 0.390 \\
\hline $\mathrm{P} 3 \mathrm{DT} / \mathrm{N} / \mathrm{TiO}_{2}$ & 0.467 & 1.060 & 0.0450 & 0.225 & 0.455 \\
\hline
\end{tabular}

lists the parameters of dye-sensitized solar cells. Under standard global AM1.5 G $\left(100 \mathrm{~mW} / \mathrm{cm}^{2}\right)$ solar condition, the P3DT-sensitized solar cell gave a short-circuit current $\left(J_{\mathrm{SC}}\right)$ of $0.733 \mathrm{~mA} / \mathrm{cm}^{2}$ and an open-circuit voltage $\left(V_{\mathrm{OC}}\right)$ of $0.401 \mathrm{~V}$, corresponding to an overall conversion efficiency $(\eta)$ of $0.115 \%$. The P3DT/N/TiO ${ }_{2}$-sensitized solar cell gave a short-circuit current $\left(J_{\mathrm{SC}}\right)$ of $1.06 \mathrm{~mA} / \mathrm{cm}^{2}$ and an open-circuit voltage $\left(V_{\mathrm{OC}}\right)$ of $0.467 \mathrm{~V}$, corresponding to an overall conversion efficiency $(\eta)$ of $0.225 \%$. The overall conversion efficiency enhancement of $\mathrm{P} 3 \mathrm{DT} / \mathrm{N} / \mathrm{TiO}_{2}$ relative to $\mathrm{P} 3 \mathrm{DT}$ can be related to the chemical interaction between P3DT and $\mathrm{N} / \mathrm{TiO}_{2}$ in the nanocomposite.

\section{Conclusion}

A new Ti-S bond and new optical properties can be found in $\mathrm{P} 3 \mathrm{DT} / \mathrm{N} / \mathrm{TiO}_{2}$ by IR, XPS, UV and PL tests. $\mathrm{CV}$ tests show that $\mathrm{P} 3 \mathrm{DT} / \mathrm{N} / \mathrm{TiO}_{2}$ has the smallest bandgap $E_{\mathrm{g}}$ of $0.97 \mathrm{eV}$ and is a kind of p-n semiconductor composite material of good performance. Solar cell performance tests indicate that the P3DT/N/TiO 2 -sensitized solar cell is better than the P3DT-sensitized solar cell. All these show that $\mathrm{P} 3 \mathrm{DT} / \mathrm{N} / \mathrm{TiO}_{2}$ is a new kind of $\mathrm{p}-\mathrm{n}$ material of good photoelectric performance.

\section{Acknowledgements}

The work was supported by the Key Planned Science and Technology Project of Hainan Province (ZDXM 20100062), and the National High Technology Research and Development Program of Hainan under Grant NO. 509013, and the National High Technology Research and Development Program of China (863 Program) under Grant NO. 2006AA03z412, and the Scientific Research Project of Hainan Education Department under Grant No.Hj 2010-52, and the Scientific Research Foundation of Graduate School of Beijing University of Chemical and Technology (No. 09Si005).

\section{References}

[1] McCullough R. D.: The chemistry of conducting polythiophenes. Advanced Materials, 10, 93-116 (1998). DOI: 10.1002/(SICI)1521-4095(199801)10:2<93::AIDADMA93>3.0.CO;2-F

[2] Tiwari A., Singh V.: Synthesis and characterization of electrical conducting chitosan-graft-polyaniline. Express Polymer Letters, 1, 308-317 (2007).

DOI: 10.3144 /expresspolymlett.2007.44

[3] Çakmak O., Baştürkmen M., Kısakürek D. O.: Synthesis and characterization of conducting and non-conducting polymers of sodium 2,4,6-trichlorophenolate by microwave initiation. Polymer, 45, 5451-5458 (2004).

DOI: $10.1016 /$ j.polymer.2004.06.049

[4] Lawandy S. N., Halim S. F., Darwish N. A.: Structure aggregation of carbon black in ethylene-propylene diene polymer. Express Polymer Letters, 3, 152-158 (2009).

DOI: $10.3144 /$ expresspolymlett.2009.20

[5] Smestad G. P., Spiekermann S., Kowalik J., Grant C. D., Schwartzberg A. M., Zhang J., Tolbert L. M., Moons E.: A technique to compare polythiophene solidstate dye sensitized $\mathrm{TiO}_{2}$ solar cells to liquid junction devices. Solar Energy Materials and Solar Cells, 76, 85-105 (2003).

DOI: 10.1016/S0927-0248(02)00252-0

[6] Vorotyntsev M. A., Vasilyeva S.: Metallocene-containing conjugated polymers. Advances in Colloid and Interface Science, 139, 97-149 (2008).

DOI: $10.1016 /$ j.cis.2008.01.006

[7] Kim J. Y., Kim S. H., Lee H. H., Lee K., Ma W., Gong X., Heeger A. J.: New architecture for high-efficiency polymer photovoltaic cells using solution-based titanium oxide as an optical spacer. Advanced Materials, 18, 572-576 (2006). DOI: $10.1002 / \mathrm{adma} .200501825$

[8] Kim J. Y., Lee K., Coates N. E, Moses D., Nguyen TQ., Dante M., Heeger A. J.: Efficient tandem polymer solar cells fabricated by all-solution processing. Science, 317, 222-225 (2007).

DOI: $10.1126 /$ science. 1141711

[9] Sharma G. D., Suresh P., Sharma S. K., Roy M. S.: Photovoltaic properties of liquid-state photoelectrochemical cells based on PPAT and a composite film of PPAT and nanocrystalline titanium dioxide. Synthetic Metals, 158, 509-515 (2008).

DOI: $10.1016 /$ j.synthmet.2008.03.026

[10] Visy Cs., Bencsik G., Németh Z., Vértes A.: Synthesis and characterization of chemically and electrochemically prepared conducting polymer/iron oxalate composites. Electrochimica Acta, 53, 3942-3947 (2008). DOI: $10.1016 /$ j.electacta.2007.07.060 
[11] Sharma G. D., Suresh P., Sharma S. K., Roy M. S.: Optical and electrical properties of hybrid photovoltaic devices from poly (3-phenyl hydrazone thiophene) (PPHT) and $\mathrm{TiO}_{2}$ blend films. Solar Energy Materials and Solar Cells, 92, 61-70 (2008).

DOI: 10.1016/j.solmat.2007.08.009

[12] Huisman C. L., Goossens A., Schoonman J.: Preparation of a nanostructured composite of titanium dioxide and polythiophene: A new route towards 3D heterojunction solar cells. Synthetic Metals, 138, 237-241 (2003).

DOI: $10.1016 / \mathrm{S} 0379-6779(02) 01310-3$

[13] Han Z. Y., Zhang J. C., Yang X. Y., Zhu H., Cao W. L.: Synthesis and photoelectric property of poly (3-octylthiophene)/zinc oxide complexes. Solar Energy Materials and Solar Cells, 94, 194-200 (2010).

DOI: 10.1016/j.solmat.2009.09.001

[14] Han Z. Y., Zhang J. C., Yang X. Y., Zhu H., Cao W. L.: Synthesis and photoelectric property of poly (3-octylthiophene)/titanium dioxide nano-composite material. Journal of Materials Science: Materials in Electronics, 21, 6, 554-561 (2010). DOI: $10.1007 / \mathrm{s} 10854-009-9956-6$

[15] Xu J-C., Liu W-M., Li H-L.: Titanium dioxide doped polyaniline. Materials Science and Engineering: C, 25, 444-447 (2005).

DOI: $10.1016 / \mathrm{j} . \mathrm{msec} .2004 .11 .003$
[16] Kang E. T., Neoh K. G., Tan K. L.: Surface modifications of poly(3-alkylthiophene) films by graft copolymerization. Macromolecules, 25, 6842-6848 (1992). DOI: 10.1021/ma00051a019

[17] Janáky Cs., Visy Cs.: Synthesis and characterization of poly(3-octylthiophene) $/ \gamma-\mathrm{Fe}_{2} \mathrm{O}_{3}$ nanocomposite $-\mathrm{A}$ promising combination of superparamagnetic-thermoelectric-conducting properties. Synthetic Metals, 158, 1009-1014 (2008).

DOI: 10.1016/j.synthmet.2008.07.014

[18] Trznadel M., Zagórska M., Lapkowski M., Louarn G., Lefrant S., Pron A.: UV-VIS-NIR and Raman spectroelectrochemistry of regioregular poly(3-octylthiophene): Comparison with its non-regioregular analogue. Journal of the Chemical Society, Faraday Transactions, 92, 1387-1393 (1996).

DOI: $10.1039 / F T 9969201387$

[19] Shi C. J., Yao Y., Yang Y., Pei Q. B.: Regioregular copolymers of 3-alkoxythiophene and their photovoltaic application. Journal of the American Chemical Society, 128, 8980-8986 (2006).

DOI: $10.1021 / j a 061664 x$

[20] Hwang S-W., Chen Y.: Synthesis and electrochemical and optical properties of novel poly(aryl ether)s with isolated carbazole and p-quaterphenyl chromophores. Macromolecules, 34, 2981-2986 (2001).

DOI: $10.1021 / \mathrm{ma} 001855 \mathrm{z}$ 